\title{
Whose citizenship anyway?
}

\author{
MORGAN GODFERY
}

Who gets to define belonging? The nation state or its citizens? The government or civil society? This article argues that, for Māori, citizenship is and has been contested and conditional. It examines the history of belonging in New Zealand, from the Treaty of Waitangi to the Citizenship Act 1977, and recommends a framework for teaching belonging and citizenship to Māori students. The idea underpinning the framework is that teaching citizenship means teaching history, or the relationship between the postcolonial state and its indigenous citizens.

\section{Introduction}

The year is 2011 and in a damp garage somewhere in South Auckland a self-styled chief is issuing passports and residence certificates. Week after week anxious migrants arrive for help from Amato Akarana-Rewi, a 78 year old who prefers the title Chief Tuapai, the leading figure in the so-called "Sovereign Aotearoa Government" (Tan, 2011a). Akarana-Rewi is issuing migrants certificates, passports and even driver licenses that promise to release their holders from any obligations under "Pākehā law". One migrant paid $\$ 370$ for a certificate. Meanwhile, in a separate but similar scheme across town, Gerard Otimi-a self-declared hapū (sub-tribe) leader-is issuing certificates and stamps that he says will permit migrants to remain in New Zealand as part of his hapū (Gay, 2011). Otimi is visiting marae across Auckland to deliver his sales pitch. One migrant paid $\$ 500$ for an unusable certificate.

It seems obvious, but it is worth stating for the record: both schemes were fraudulent. According to Immigration New Zealand the documents Akarana-Rewi was issuing were worthless (Tan, 2011b). The "Sovereign Aotearoa
Government" was a fiction. The same is true of Otimi's certificates and stamps. They have "no real meaning", said Judge Wiltens in the District Court (Gay, 2011).

Otimi was facing 38 charges of altering a document with the intent to cause loss and, in a bizarre twist, Akarana-Rewi attended the hearing as a supporter, even going as far as directly addressing the judge and questioning his "authority" to override Māori law.

In the end, Otimi was found guilty and sentenced to eighteen months in prison.

If you were to ask the average New Zealander what they know of Māori and citizenship I imagine many would shrug their shoulders and mumble something about a fraudulent passport scheme they read in the news. Those who know their history might cite Article 3 in the Treaty of Waitangi-the clause promising Māori the rights and privileges of British subjects — while the special few might discuss Āpirana Ngata's thoughts on the price of citizenship. This article aims to put each of those responses in context, exploring how tikanga (here glossed as Māori law or a normative system) actually regulates belonging and how New Zealand citizenship has been, for Māori, contested and conditional. The 
article concludes with suggestions for acknowledging and teaching citizenship with methods that are sensitive to how Mãori have experienced New Zealand citizenship.

\section{Belonging in te ao Māori}

One cannot make sense of belonging and citizenship without understanding history. In discussing belonging in te ao Māori, the Māori world, Hirini Moko Mead (2003) uses a striking metaphor: kaihau-waiu, meaning property or attributes gained through the mother's milk. Kaihauwaiu is a birthright with attributes that Mead organises into two different categories:

I. those that anchor an individual within a social unit (e.g., descent)

2. those that are "fundamental to the very nature of human life" (p. 4I) (e.g., personal interests, or achievements in art or politics).

The first category concerns belonging and its rights and responsibilities, for example, the right to claim membership of a certain hapū. The second category concerns the rights and responsibilities of individuals, such as the right to claim status as a tohunga (translated in this context as expert) in a certain field (e.g., art). Yet, as Mead explains, the "fundamental" attribute of the kaihau-waiū is whakapapa, or the gift of birth. Whakapapa is loosely translated to mean descent, but the term encompasses more than the biological. It also refers to a set of social rights, obligations and theories of belonging. According to Mead, whakapapa provides our identity within the social unit.

Take the idea of a türangawaewae, or a person's place to stand. One's tūrangawaewae is an inheritance of birth. This understanding of whakapapa and tūrangawaewae shares some conceptual ground with the jus soli, or the right of the soil. The jus soli is an inheritance from Athenian and Roman law and, in its modern application, means anyone born within a certain locality, territory, or state is entitled to nationality or citizenship (Sawyer, 2013). ${ }^{1}$ Citizenship, in Hannah Arendt's famous formulation, is "the right to have rights" (Krause, 2008) and whakapapa is part of the right to a turrangawaewae.

While it is tempting to compare Māori forms of belonging with citizenship, the comparisons can only go so far. Where a person's tūrangawaewae comes from his or her whakapapa-that is, something internal to themcitizenship relies on external recognition from a nation state. That contrast may seem abstract so consider it this way: while it is possible for a citizen to become "stateless" that is, to lose the state's recognition-it is not possible for someone to become whakapapa-less. ${ }^{2}$ Where citizenship is bestowed by a nation state it can also be revoked by a nation state, but hapū cannot revoke whakapapa.
Yet this is not to suggest that a person with whakapapa to a hapū can always claim belonging in precisely the same way. In some circumstances, perhaps where a hara (offence) is committed, the hapū might remove or alter a person's standing within the group. Where this happens, tikanga regulates the hapü's process and outcome. In simple terms, tikanga is law-defined as the right, correct or just way of doing things (Jackson, 1988)—but it is also a normative system embracing more than the strictly legal: it operates across politics, philosophy, culture, religion, and more. Tikanga is, in turn, based on a series of fundamental values such as whanaungatanga and manaakitanga (Jones, 2014) and these values inform the rules that regulate belonging. This interrelationship between rules and values is one reason why tikanga is sometimes referred to simply as "ethical behaviour" (Mikaere, 2011, p. 109).

The tikanga regulating belonging can become complex, but for the purposes of this article it is enough to examine two well-known categories: tangata whenua, loosely translated for this context as local people, and manuhiri, loosely translated as guests.

Tangata whenua is a determinist category while manuhiri is a relational category. To flesh that out, take this example: while I make my home in Thorndon, the old Wellington colonial suburb that the tangata whenua call Pipitea, I cannot claim—despite identifying as Mãori-tangata whenua status here. Tikanga would not allow it, even if I went as far as securing land or marrying into the local hapū. This is not to say I am necessarily an outsider with no stake in the community, it is only to say that my belonging to the area is different (my kaihau-waiu is different). The tangata whenua of the area are those with whakapapa ties to it. In this sense, the category is historically determined (based on an ancestral right). But what I can claim is manuhiri status based on my relationship to the tangata whenua- $\mathrm{I}$ am a visitor on their land, and thus my status is relational.

Of course, there are different ways of belonging and the values and rules governing the tangata whenua/ manuhiri distinction are not immutable. Tangata whenua can enlarge their communities with marriages, land grants or simply invitations to participate in the community without needing to transform a person's whakapapa. Extending belonging and its rights and obligations is a social act (Mikaere, 2011). Perhaps the quintessential example of tangata whenua enlarging their community is the Treaty of Waitangi, the 1840 agreement that reaffirmed rangatiratanga (unfettered chieftainship) for Māori and created kāwanatanga (governorship) for the Crown (Hohepa, 2010). 


\section{Choosing the hapū or the nation state?}

Today, a person can still belong to their hapū, but this is not relevant to their New Zealand citizenship. Under the Citizenship Act 1977, New Zealand citizenship is essentially a bureaucratic threshold: a person is a citizen if she or he were born in the country to at least one parent who is a citizen or permanent resident at the time. ${ }^{3}$ The wider idea of a "citizenship regime" is seen in similar terms, with one prominent scholar simply defining it as "the institutional arrangements, rules and understandings that guide and shape concurrent policy decisions and expenditures of states (Humpage, 2008, p. 248).

There are also philosophical, sociological and cultural ways of defining citizenship (it is not merely legalistic), like Kymlicka's argument that citizenship is a means for governments to build unity and foster a sense of solidarity between individuals. ${ }^{4}$ In other countries, these definitions might suit their circumstances just fine. But the context in New Zealand is different. While Article 3 of the Englishlanguage text of the Treaty of Waitangi promises Māori all of the "rights and privileges of British subjects" citizenship, essentially_Article 2 of the Māori text of the Treaty guarantees that the rangatira signing it retain their tino rangatiratanga (unfettered chieftainship). The implication of the two guarantees is that Māori forms of belonging, regulated by tikanga, would remain and British citizenship would exist alongside it.

In other words, one can argue the Treaty lends itself to two categories of belonging: Tangata Whenua-the people of the land, or the indigenous people-and Tangata Tiriti-the people of the Treaty, or the nonindigenous New Zealanders who can claim belonging according to the Treaty. In theory the impact of this is that post-1840 there are different ways Māori can belong to the same land. They can belong according to Māori values and rules, and they can belong according to the new values and rules of the kāwanatanga, citizenship under the New Zealand nation state.

Two forms of belonging with their histories and privileges and obligations must have been an inspiring possibility for the young nation. The problem, in practice, is the kāwanatanga (meaning, in this context, the settler government) did not formally recognise and accommodate belonging under tikanga. In fact, British and then New Zealand citizenship was seen as "a first step in 'protecting' Māori from society and themselves by encouraging them to become more 'civilised' through the abandonment of tribal collectivism" [my emphasis] (Humpage, 2008, p. 250).

Thus, the expectation of the kāwanatanga was that their citizenship system would replace Māori systems of belonging. Yet for the rangatira who signed the Treaty in 1840 the expectation was that their system would co- exist with the newcomers' system. As Claudia Orange explains, the implications of British citizenship — that those who took it would submit to British law- "were not emphasised" to the Māori signatories (Orange, 2011, p. 49). Instead the rangatira who signed did so to reaffirm their rangatiratanga (unfettered chieftainship) while creating kāwanatanga (governorship) for the Crown (Waitangi Tribunal, 2014).

On this reading one can argue that a form of citizenship that does not recognise and provide for Māori systems of belonging is a breach of the Treaty.

\section{Citizenship: Conditional and contested}

With the Treaty signings complete, the colonial government set about establishing its "substantive sovereignty" with a form of political citizenship designed to "bring Māori within the compass of British authority" (Orange, 2011, p. 153). In 1867 the colonial government-on the initiative of the Native Secretary Donald McLean-went about extending voting rights to property-holding Māori men. Māori were allocated four seats in Parliament under the Māori Representation Act on the expectation that political citizenship rights under the kāwanatanga would help undercut the emerging movements for rangatiratanga such as the Māori King movement (Kīngitanga) and the Māori Parliament (Paremata Māori).

In one sense, the tactic worked: come the turn of the 20th century most Māori were fully assimilated into the New Zealand political and citizenship system. But in another sense, Māori themselves were contesting the meaning of their citizenship. In the 19th and 20th centuries many hapū and iwi (tribes) were still participating in parallel political structures such as tribal rūnanga or assemblies where decisions over things like communal work were made (Walker, 2004). Participating in parallel structures such as rūnanga meant contesting the kāwanatanga assertion that the New Zealand citizenship system operates to the exclusion of other systems of belonging.

In any case, for many Māori in the 19th and 20th centuries their citizenship was conditional on identifying as a New Zealander first. Even as the First Labour Government set about transforming the political citizenship system to a social-citizenship system where social rights were equal with procedural (i.e. political) rights such as voting, the governing principles of each system were still operating to exclude Māori systems of belonging.

Under the First Labour Government and its socialcitizenship system the main mechanism for securing 
social rights was the welfare state (McClure, 1998). But under the welfare state and the social-citizenship system governments did not see their obligations to Māori through a constitutional lens (that is, the Treaty) or a historical lens (colonialism), but through a civil-rights lens: the relationship was transactional and individual, between state and citizen. Mason Durie calls this the ideology of the welfare state (Durie, 2005).

This relationship between state and citizen is more than abstract. While the welfare state operates on universal principles, that universalism can sometimes work to exclude Māori and subsume difference. Take the Unsupported Child's Benefit as an example: under section 29 of the Social Security Act 1964-the empowering act for the welfare state-whāngai situations where a Māori parent or parents adopt a child under tikanga will not meet the eligibility criteria. To claim support the whānau must prove that there has been a "family breakdown".

In this case, the Act is making an assumption about how families operate-an assumption that does not reflect Māori realities. Whāngai situations rarely involve a family breakdown, instead it could be as simple as a grandparent raising his or her first mokopuna (grandchild) in an effort to pass on knowledge and expertise in, say, the whānau whakapapa. In this case the mechanism for securing social rights - the welfare stateends up excluding Māori in whāngai situations from their full rights under a social-citizenship system.

In other words, even though the social-citizenship system and the welfare state are not explicitly discriminatory, their universal principles make assumptions that can operate to exclude certain forms of Māori social organisation. This dynamic can also operate in reverse: during World War 2 Māori were paid less under the wartime benefits scheme on the assumption that they could simply go home to the pā (village) and resume a form of subsistence living (Orange, 1977). In this case, Māori social organisation was not excluded but used as an explicit excuse to reduce entitlements. Thus, New Zealand citizenship for Māori has often operated as a kind of conditional citizenship, with the universalist pursuit of social rights sometimes working to exclude Māori realities.

\section{Teaching inclusive citizenship}

This is where Mr Akarana-Rewi and Mr Otimi return. While we must acknowledge that their citizenship schemes were exploitative, selfishly preying on some of the most vulnerable members of society, we might also acknowledge that the idea underpinning each schemethat it is possible to run a separate system of belongingis not so far-fetched. ${ }^{6}$
Indeed, Māori antipathy towards the New Zealand citizenship scheme is not uncommon. One study found that, of the ethnic groups surveyed, "Māori participants were least likely to say citizenship was an important identity for them, with less than one-tenth giving this response." In addition, "none associated it with "national identity" or "belonging" given they tended to have a very negative viewpoint on citizenship due to its association with breaches of the Treaty of Waitangi" (Humpage, 2010, p. 16).

One can explain this antipathy with history, in particular the failure to recognise Māori systems of belonging as equivalent to citizenship and the failure to extend a form of citizenship that takes note of and provides for difference. Perhaps what is necessary is a form of differentiated or post-sovereign citizenship, where group-differentiated rights supplement universal rights. Under a differentiated system, universal mechanisms such as the welfare state could incorporate cultural difference (perhaps meaning that whāngai situations would no longer be ignored by the law).

Yet the point of this brief historical narrative is to demonstrate that it is necessary to teach citizenship as contested ground. Simply teaching the formal position such as the legislative thresholds for citizenship means denying one aspect of Māori students' identity, their kaihau-waiū, while unintentionally elevating another form of belonging, their New Zealand citizenship. This is not to say teaching must become politicised; only that it must be anchored in its historical context and responsive to the unique experience and perspective a Māori student is bringing to the classroom.

Table 1 presents an indicative framework for teaching citizenship that incorporates Māori history and is sensitive to Māori students' experiences. The framework is based on the recurring practices from email interviews with twelve high school teachers in North Island schools about what, in their teaching experience, works with students when teaching about questions of identity and history. The model should be treated as a guide rather than a rule as the interview respondents were self-selecting rather than random, all taught NCEA history, or NCEA geography, or Year 9 and 10 social studies, and the sample size is small. Each individual teacher is in the best position to judge what method will work with their students.

The framework in Table 1 focuses on two key elements to Māori students' success: "strong relationships" (Whitireia, 2012) and group participation (Higgins, n.d). Strong relationships can be seen as the value underpinning the entire framework-earning the trust of Māori students is essential if the teacher is going to teach their history - and group participation could be seen as the primary method. Student participation helps 


\begin{tabular}{|c|c|c|}
\hline PURPOSE & METHOD & CONTEXT \\
\hline $\begin{array}{l}\text { Build trust between } \\
\text { the teacher and } \\
\text { student }\end{array}$ & $\begin{array}{l}\text { Student-directed learning: } \\
\text { - How do students think about citizenship? } \\
\text { - What do they know about the Treaty of } \\
\text { Waitangi? } \\
\text { - Given what they know and what they don't, } \\
\text { what would students like to learn? }\end{array}$ & $\begin{array}{l}\text { This method would involve contributed material alongside the set } \\
\text { materials. } \\
\text { E.g., Students could convene groups, determine how much they } \\
\text { know and what knowledge gaps they would like to fill. This helps } \\
\text { give students a stake in the learning. Special attention should be } \\
\text { given to gaps in knowledge about Māori and citizenship. }\end{array}$ \\
\hline $\begin{array}{l}\text { Ground students in } \\
\text { the essential material, } \\
\text { especially the history } \\
\text { of Māori, their } \\
\text { indigenous forms of } \\
\text { belonging and New } \\
\text { Zealand citizenship }\end{array}$ & $\begin{array}{l}\text { Teacher-directed learning: } \\
\text { - In light of the student responses above, } \\
\text { what is the essential context they need to, } \\
\text { first, ground themselves in the subject and, } \\
\text { second, fill their particular knowledge gaps? }\end{array}$ & $\begin{array}{l}\text { This method means introducing the historical context. The effect of } \\
\text { doing so is twofold: first, students gain the information they need } \\
\text { to make sense of the subject and, second, attention is paid to the } \\
\text { particular status of Māori as New Zealand citizens and indigenous } \\
\text { people with their own systems of belonging. }\end{array}$ \\
\hline $\begin{array}{l}\text { Develop shared } \\
\text { understanding between } \\
\text { Māori students and } \\
\text { non- Māori students }\end{array}$ & $\begin{array}{l}\text { Teacher-directed learning: } \\
\text { - Given the composition of the class and the } \\
\text { different perspectives on citizenship, what } \\
\text { is the best way to engage students with the } \\
\text { different perspectives within the class? }\end{array}$ & $\begin{array}{l}\text { This method involves teaching comparative material. For example, } \\
\text { asking students to compare and contrast Māori systems of } \\
\text { belonging with the current system of New Zealand citizenship. This } \\
\text { helps develop shared understanding between students. For classes } \\
\text { with particular grounding in the historical material, a discussion on } \\
\text { how to accommodate both forms of belonging may help students } \\
\text { understand that belonging under tikanga is not inferior to belonging } \\
\text { under parliamentary legislation. }\end{array}$ \\
\hline $\begin{array}{l}\text { Assess the } \\
\text { effectiveness of the } \\
\text { methods }\end{array}$ & $\begin{array}{l}\text { Inquiry-based learning: } \\
\text { - Do students feel their knowledge gaps have } \\
\text { been filled? } \\
\text { - Are students confident enough to lead a } \\
\text { discussion on the different ways of belonging } \\
\text { to this land? }\end{array}$ & $\begin{array}{l}\text { This method involves no new material, only feedback for the } \\
\text { purposes of gauging how effective the teaching has been and } \\
\text { reinforcing student learnings. }\end{array}$ \\
\hline
\end{tabular}

\section{TABLE 1. AN INDICATIVE FRAMEWORK FOR TEACHING CITIZENSHIP THAT INCORPORATES MĀORI HISTORY AND IS SENSITIVE TO MĀORI STUDENTS' EXPERIENCES}

identify not only the knowledge the teacher must impart, but it also gives each student a stake in the classroom experience, allowing a degree of shared understanding to develop between the students themselves and between the teacher and the students.

\section{Conclusion}

This article recommends grounding the teaching of citizenship in its historical context. It concludes that, for civics and citizenship education to work for Māori, teachers and teaching must be sensitive to history and Māori forms of belonging.

\section{Notes}

I New Zealand law operates under a kind of qualified jus soli, though some other Western countries retain a right of the soil in its widest sense, for example the United States where any person born in the country is entitled to citizenship.

2 Statelessness is the absence of citizenship or nationality. One example of a stateless person could be a refugee who has been stripped of his or her citizenship, say for political activism in the home country, and has yet to gain citizenship or nationality from another nation state. New Zealand offers citizenship to stateless people born in the country, as explained further in the article.
3 See the Citizenship Act 1977, section 6.

4 Humpage outlines this argument, though for the full analysis see Kymlicka (1996).

5 In this context Orange is referring to de-facto rather dejure sovereignty. (See Orange, 20II, p. I3.)

6 It is also important to note that Akarana-Rewi and Otimi's citizenship schemes, although drawing on a certain history, are likely to fail as a matter of tikanga. Tikanga demands manakitanga — or caring for others-and exploitative citizenship schemes offend the manaakitanga principle.

\section{References}

Durie, M. (2005). Nga tai matatū: Tides of Mãori endurance. Auckland: Oxford University Press.

Gay, E. (2011). Passport scammer 'preyed on vulnerable'. Retrieved from: http://www.nzherald.co.nz/nz/news/article. cfm?c_id=1\&objectid=10741787

Higgins, J. (n.d). Effective teaching strategies for Mãori students in an English-medium numeracy classroom. Retrieved from: http://nzmaths.co.nz/sites/default/files/Numeracy/ References/comp_higgins1.pdf

Hohepa, P. (2010). Linguistic evidence in the matter of the Treaty of Waitangi Act 1975 and the Te Paparahi i te Raki inquiry. Retrieved from: http://nwo.org.nz/files/Patu-HohepaWAI1040.pdf 


\section{HE WHAKAARO ANO}

Humpage, L. (2008). Revision required: Reconciling New Zealand citizenship with Māori nationalisms. National Identities, 10(3), 247-261. https://doi. org/10.1080/14608940802249858

Humpage, L. (2010). New Zealand attitudes to social citizenship in the context of neoliberalism. Retrieved from: https:// cdn.auckland.ac.nz/assets/arts/documents/nz_social_ citizenship_executive_report.pdf

Jackson, M. (1988). The Mãori and the criminal justice system: A new perspective-He whaipaanga hou. Wellington: Department of Justice.

Jones, C. (2014). A Māori constitutional tradition. New Zealand Journal of Public and International Law, 12(1), 187-240.

Krause, M. (2008). Undocumented migrants: An Arendtian perspective. EJPT, 7(3), 331-348. https://doi. org/10.1177/1474885108089175

Kymlicka, M. (1996). Multicultural citizenship. Oxford, UK: Oxford University Press. https://doi. org/10.1093/0198290918.001.0001

McClure, M. (1998). A civilised community: A history of social security in New Zealand, 1898-1999. Auckland: Auckland University Press.

Mead. M. (2003). Tikanga Mãori: Living by Mãori values. Wellington: Huia Publishers.

Mikaere, A. (2011). Colonising Myths: Mãori Realities. Wellington: Huia Publishers.

Orange, C. (1977). A kind of equality: Labour and the Mãori people 1935-1949. Unpublished master's thesis, University of Auckland.

Orange, C. (2011). The treaty of Waitangi (2nd ed.). Wellington: Bridget Williams Books. https://doi. org/10.7810/9781877242489

Sawyer, C. (2013). The loss of birthright citizenship in New Zealand. VUWLR, 44, 653-674.

Tan, L. (2011a). Claims licensed immigration advisers may be tied into scam. Retrieved from: http://www.nzherald.co.nz/nz/ news/article.cfm?c_id=1\&objectid=10720207
Tan, L. (2011b). Citizenship scammer hits again. Retrieved from: http://m.nzherald.co.nz/indigenous-peoples/news/article. cfm?c_id=464\&objectid=10719679

Waitangi Tribunal. (2014). He whakaputanga me te tiriti: The declaration and the treaty: The report on stage 1 of the Te Paparabi o Te Raki inquiry, Wai 1040. Wellington: Author.

Walker, Ranginui. (2004). Ka whawhai tonu matou: Struggle without end (2nd ed.), Auckland: Penguin Books.

Whitireia. (2012). Sharing successful teaching and learning strategies for Māori, Pacific, and youth learners. Retrieved from: https://akoaotearoa.ac.nz/download/ng/file/group-6/ sharing-successful-teaching-and-learning-strategies-formaori-pacific-and-youth-learners.pdf

Morgan Godfery is a writer and trade unionist based in Wellington. He is the editor of The Interregnum, published by Bridget Williams Books in 2016, and an online columnist for Overland Literary Journal, a non-fiction book reviewer for Fairfax and a judge for the Ockham New Zealand Book Awards. Morgan also appears on radio and television as a political commentator and has authored several academic chapters and journal articles on Māori politics. He graduated in law from Victoria University in 2015 and works for FIRST Union, the secondlargest private-sector trade union in New Zealand.

Email: morgan.godfery@gmail.com 